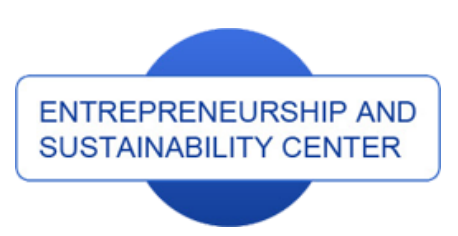

Publisher

http://jssidoi.org/esc/home enterprise

europe

network



Business Support on Your Doorstep

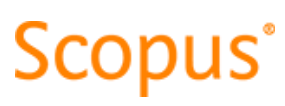



Clarivate
Analytics

\title{
INDUSTRIAL COOPERATION AND ITS INFLUENCE ON SUSTAINABLE ECONOMIC GROWTH
}

\author{
Alena V. Fomina ${ }^{1}$, Oksana N. Berduygina ${ }^{2}$, Alexander A. Shatsky ${ }^{3}$ \\ ${ }^{1}$ JSC "Central Research Institute of Economy Management and Information Systems "Electronics”, \\ 12, Kosmonavta Volkova Str., Moscow, 127299, Russian Federation \\ ${ }^{2}$ Tyumen Industrial University, \\ 38, Volodarskogo Str., Tyumen, 625000, Russian Federation \\ ${ }^{3}$ Russian State Social University, \\ 4/5, Wilhelm Pieck Str., Moscow, 129226, Russian Federation, \\ E-mails: ${ }^{1}$ fomina_a@instel.ru $;{ }^{2}$ berduygina@ymservices.ru; $;{ }^{3}$ kratida@yandex.ru
}

Received 15 July 2017; accepted 10 January 2018; published 30 March 2018

\begin{abstract}
The stability of economic development is determined by the features of the network structure in collaborative engagement of enterprises. Industrial cooperation is just one part of that process; it differs in spatial coverage and range of activity. The complexity of taking into account the synergistic effect that arises in this case stresses the importance of this question from the theoretical and practical points of view. For this purpose, the paper considers the essence of industrial cooperation, some approaches to agglomerative tendencies and conceptual visions of cooperation from the standpoint of institutional theory. The investigation of the influence of cooperation on economic growth is based on several hypotheses. The first one is about the positive correlation between the studied parameters; the second one is about the fact that protection of institutional property rights is an important factor in cooperation development. These theories have been studied within the frame of loglinear model using the table of data about 20 European countries for the forecast period of 2017-2021. The results show that the mature system of industrial cooperation allows providing an additional economic growth at the level of 2.3-3.0\%. It is also important to conclude that cooperation enhances the factor impact of the usual determinants of economic growth (working labor, capital and export). The model also takes into account some other possible determinants of economic growth such as expenses on research and development, use of a right of intellectual property and the Index of Economic Freedom. At the same time, a lax regulation in the sphere of property rights protection can become an incentive for co-operators. These and some other provisions determine the ways of enhancing of activity of enterprises for their close collaboration; it is emphasized that the development of co-operational relations has a great impact on competitiveness and sustainability.
\end{abstract}

Keywords: industrial cooperation, determinants of economic growth, integrated entities, effects of cooperation, sustainable economic growth

Reference to this paper should be made as follows: Fomina, A.V.; Berduygina, O.N.: Shatsky, A.A. 2018. Industrial cooperation and its influence on sustainable economic growth, Entrepreneurship and Sustainability Issues 5(3): 467-479. https://doi.org/10.9770/jesi.2018.5.3(4)

JEL Classifications: C52, D22, E66 


\section{Introduction}

One of the basic conditions of progressive advance is integrating efforts of a lot of economic agents. The sustainability of an enterprise is determined by the set of its inherent resources, the degree of effectiveness of their use and good conditions for production cooperation with other industrial enterprises of the region or industry. Cooperative interaction compensates for the lack of certain resources in a particular enterprise due to their redistribution, which ensures the continuity of the reproduction cycle (Petrishcheva, 2011; Zheng, \& PosselDölken, 2002; Bonin, \& Putterman, 2013; Restakis, 2010; Ignatavičius et al., 2015; Prause, Atari, 2017). The development of cooperation is historically conditioned by the natural process of growth of the social division of labor. The new factors of industrial cooperation arise, first of all, under the influence of profound changes in the very process of production and globalization. Traditionally, with the cooperation of industrial enterprises, the task is to maximize the effective use of the potential of each of the industries in terms of specialization and a unique set of competencies. The development of co-operation, as well as the growth of specialization, concentration and combination of production, confirms the intensification of the process of their socialization. Increasing competition impels the subjects of the economy to search for more stable forms of cooperation, stimulates the emergence of integration entities that differ in the ways of interconnection and management. In this connection, it is reasonable to stimulate progressive mechanisms of production cooperation.

The principle of integration of science, education and industry creates a solid foundation for the development of sustainable cooperation of companies. At the present stage of the functioning of economic systems, it is impossible to consider industrial cooperation as a strictly intra-economic process. It is important to understand that such cooperation extends both to production itself and to activities that precede or follow it (Obecny, \& Sanders, 2017; Kozma, 1982). Despite the fact that cooperation primarily focuses on achieving the end result, it is necessary to use an integrated approach and take into account the practical aspects of cooperation.

As researchers note, many sectoral and regional entities formed like this are experiencing problems. These problems include, among others, the low efficiency of the activities of integration entities (Yin, 2016); the need for their reorganization and, in some cases, changing the form of ownership (Paprzycki, 2005; Kuroiwa, 2012) (it seems that it is the institutional protection of property rights that is a significant factor in the development of cooperation; we are going to try to confirm this hypothesis later in the course of the study), as well as the risk of disintegration of the interfirm structure, which as a result may lead to a change in the configuration of industrial complexes (Haller, 2008). As a key reason for these problems, one can consider the random principle of forming the composition of integrated entities, the lack of justification for their territorial binding and the solution of predominantly auxiliary transaction tasks instead of the main transformational ones. All this leads to the need for a detailed study of the phenomenon of industrial cooperation and determining the degree of its impact on the region's sustainable economic growth.

\section{Literature review}

There are many debates on the essence and content of cooperation in modern economic science. The consideration of the problem initially involves studying the fundamental theory of the cooperative system. We can find in the literature the term "co-operation of production" or "production co-operation". In our opinion, cooperation and cooperation are related concepts. So, co-operation is a dynamic process of interaction of enterprises based on their key competence for the production and sale of products or services. Co-operation is also understood as planned-organized production links between enterprises (Akhtaryev, 2010). As a consequence of the development of specialization, production co-operation is characterized by a relative constancy and stability of 
The International Journal

ENTREPRENEURSHIP AND SUSTAINABILITY ISSUES

ISSN 2345-0282 (online) http://jssidoi.org/jesi/

2018 Volume 5 Number 3 (March)

http://doi.org/10.9770/jesi.2018.5.3(4)

ties (Berg et al., 2017), strict observance of technical conditions (De Groot, \& Plantinga, 1992). In its essence, the concept is linked with the term of cooperation as a form of long and stable ties between enterprises of the same profile that are located in different regions and jointly produce certain products. Co-operation of production can also be defined as a form of long-term production links between specialized enterprises or their associations (Bilorus, \& Bilorus, 1990). A number of researchers focus on the characteristics of independence (autonomy of decision-making without taking into account the sign of a single title of ownership) and the targeting of products (Shevchenko, \& Savinova, 2009). As a result, the most important features of industrial cooperation are (Rodina, 1990): (1) long-term economic ties; (2) joint or technologically related activities; (3) savings from specialization effects and increased labor productivity; (4) improvement and optimization of the production cycle.

It is necessary to distinguish two interrelated trends in industrial cooperation. Firstly, it is a form of management related to the production process, since the obligations of the participants in the cooperation, although they are delineated, are aimed at the production of a certain product. Secondly, cooperation also provides for the exchange between co-operators of products and services produced. Thus, industrial cooperation includes both the actual production process and the exchange of resources necessary for the production process (information, experience in marketing and management, technology, etc.). A cooperative network form of interaction unites several companies into a single structure that enhances their competitive advantages (Nikulina, \& Kuznetsov, 2016). Intercompany cooperation compensates for the lack of certain resources at a particular enterprise due to their redistribution (Gomes-Casseres et al., 2006; Glaister, \& Buckley, 1996; Adams, \& Marcu, 2004), which ensures the continuity of the reproductive economic cycle.

Approaches to the formation of integration associations are diverse. We can single out a technological approach, which involves the unification of enterprises along the technological chain (at the same time, technological compatibility and specificity of assets are assessed) (Soboleva, 2007); as well as a situational approach - the main goal of the formation of a large structure is the survival, preservation of enterprises (Semenov, 2011). At the same time, the strategic prospects for interregional cooperation largely stem from the trends in the development of industrial cooperation at local levels. Practice shows that effective cooperation in modern business conditions determines the importance of a functional approach to the formation and improvement of the work of organizational management structures (Soboleva, 2007; Batkovskiy et al, 2017).

The degree of effectiveness of industrial cooperation is significantly influenced by environmental conditions (market conditions, degree of competitiveness, sectoral entry and exit barriers, and freedom of movement of capital and resources, access to information) that are expressed in institutional security (Obecny, \& Sanders, 2017) .

Institutional and neoinstitutional economic theory allows us to consider industrial cooperation as one of the states of a possible equilibrium of economic agents in the process of market interaction (from the standpoint of game theory, where there are four fundamental problems - coordination, compatibility, cooperation and justice) and as an instrument to reduce the level of transaction costs (Bulatov, 2010a). The consideration of industrial cooperation only in the vein of neoclassical economic theory is insufficient, especially in understanding it in the broad sense, as a kind of institution.

Considering the above, we have defined production cooperation as a system of economic relations between business entities for the realization of a full or partial production cycle in order to optimize costs and increase the competitiveness of each of the participants. Considering the object of industrial cooperation, it is advisable to address the issue of evaluating cooperative network links and analyzing the impact of cooperation on economic growth through institutional parameters. 


\section{Methods and Data}

The main hypothesis of the study is that the institutional protection of property rights is a significant factor in the development of cooperation. Based on this theoretical concept, we focus on the impact of such an institutional variable as the level of state regulation in the field of protection of property rights. To do this, we are going to investigate the cause and effect relationship between the protection of property rights and the development of an industrial strategy of companies for 20 European countries for the period of 2017-2021 (the choice between adherence to autonomy or integration and cooperation), and to determine the degree of systemic influence on growth of cooperative activity for a number of countries for the forecast period of 5 years. The predicted values of the initial model parameters are obtained by the regression method (based on the data of Eurostat and CECOPCICOPA Europe is the European Confederation of Industrial and Service Cooperatives).

The evaluation of cooperative links is carried out on the basis of a logarithmic linear model through the correlation of economic growth (GDP) in logarithms for each of 20 countries in the corresponding year $t$ to the following factors - capital $\left(\mathrm{K}_{\mathrm{it}}\right)$ in logarithms, which we define as gross capital formation; labor force $\left(\mathrm{L}_{\mathrm{it}}\right)$ in logarithms, which we define as the number of employees; export of goods and services $\left(\mathrm{EXP}_{\mathrm{it}}\right)$ in logarithms; import of goods and services $\left(\mathrm{IMP}_{\mathrm{it}}\right)$ in logarithms; foreign direct investment $\left(\mathrm{FDI}_{\mathrm{it}}\right)$ in logarithms; cooperative variable as the number of co-operators (FRAN_1 $1_{\text {it }}$ ) in logarithms (Table A of the annex); and alternatively, as the number of enterprises in the cooperative sector (FRAN_2 ${ }_{\mathrm{it}}$ ), in the logarithms (Table B of the annex).

We use the log-linear specification of the model through the equation:

$$
\operatorname{FRAN}_{i t}=a_{1} I N S T I T U T_{i t}+c_{i}+u_{i t}
$$

where FRAN $_{\mathrm{it}}$ is the cooperative activity in the country $\mathrm{i}$ in the year $\mathrm{t}$ in logarithms; INSTITUT $_{\mathrm{it}}$ is an institutional variable of state regulation in the field of protection of property rights in the country $i$ in the year $t$, in logarithms; $\mathrm{c}_{\mathrm{i}}$ is unobservable fixed (by country) effect; $\mathrm{u}_{\mathrm{it}}$ is an error.

To overcome various problems in the evaluation equation, we use the analysis of data with fixed-effect transformation to eliminate heterogeneity by country. As for other econometric problems in the assessment equation, endogeneity in particular, we believe that it is regulation in the protection of property rights that affects the expansion or reduction of industrial cooperation in the country.

The measurement of cooperative activities FRAN $_{\mathrm{it}}$ is carried out through two alternative indicators:

A. cooperation from the point of view of the cooperator - an indicator of the number of cooperative parameters in the country $i$ in the year $t$ in logarithms (FRAN_ $1_{\text {it }}$ );

B. industrial cooperation from the point of view of the cooperator is an indicator of the number of cooperative productions in the country $i$ in the year $t$ in logarithms (FRAN_2 it).

The measurement of the institutional variable of state regulation in the field of protection of property rights INSTITUT $_{\text {it }}$ is carried out according to the following alternatives:

A. the Index of Economic Freedom, which is published by the Heritage Foundation and the Wall Street Journal, in logarithms $\left(\mathrm{IEF}_{\mathrm{it}}\right)$;

B. the International Property Right Index (the subindex of the Index of Economic Freedom, which is published by the Heritage Foundation and the Wall Street Journal) in logarithms (IPR $\left.{ }_{i t}\right)$. 
The International Journal

ENTREPRENEURSHIP AND SUSTAINABILITY ISSUES

ISSN 2345-0282 (online) http://jssidoi.org/jesi/

2018 Volume 5 Number 3 (March)

http://doi.org/10.9770/jesi.2018.5.3(4)

The presence of the heterogeneity of the country $c_{i}$ in the equation (1) means that INSTITUT $\mathrm{T}_{\mathrm{it}}$ can correlate with such characteristics of the country as location and distance (by analogy with the gravitational theory). These

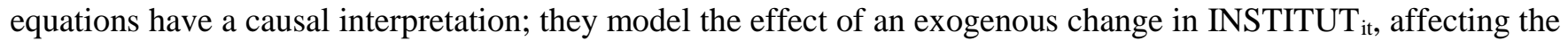
level of cooperative activity (when fixing factors in exogenous variables). We believe that our measurement of the institutional variable remains purely exogenous, as proved above.

Table 1. Correlation analysis of model parameters

\begin{tabular}{|c|c|c|c|c|c|c|c|c|c|c|c|c|}
\hline Index & $F R A N_{-} 1$ & FRAN_2 & IEF & $I P R$ & $G D P$ & $K$ & $L$ & IMP & $E X P$ & $R D$ & $R O Y$ & FDI \\
\hline FRAN_1 & 1.00 & & & & & & & & & & & \\
\hline$F R A N \_2$ & 0.02 & 1.00 & & & & & & & & & & \\
\hline$I E F$ & 0.26 & 0.08 & 1.00 & & & & & & & & & \\
\hline$I P R$ & 0.40 & 0.02 & 0.93 & 1.00 & & & & & & & & \\
\hline$G D P$ & 0.85 & 0.09 & 0.50 & 0.57 & 1.00 & & & & & & & \\
\hline$K$ & 0.82 & 0.11 & 0.49 & 0.57 & 0.99 & 1.00 & & & & & & \\
\hline$L$ & 0.78 & 0.09 & 0.05 & 0.14 & 0.81 & 0.80 & 1.00 & & & & & \\
\hline$I M P$ & 0.77 & 0.09 & 0.58 & 0.64 & 0.97 & 0.97 & 0.77 & 1.00 & & & & \\
\hline$E X P$ & 0.73 & 0.09 & 0.61 & 0.68 & 0.95 & 0.95 & 0.74 & 0.99 & 1.00 & & & \\
\hline$R D$ & 0.21 & 0.07 & 0.67 & 0.77 & 0.42 & 0.44 & 0.05 & 0.49 & 0.55 & 1.00 & & \\
\hline$R O Y$ & 0.72 & 0.10 & 0.61 & 0.63 & 0.84 & 0.83 & 0.65 & 0.90 & 0.91 & 0.44 & 1.00 & \\
\hline$F D I$ & 0.49 & 0.10 & 0.50 & 0.52 & 0.65 & 0.67 & 0.51 & 0.75 & 0.76 & 0.37 & 0.78 & 1.00 \\
\hline
\end{tabular}

Note:

$\mathrm{IEF}_{\text {it }}$ - index of economic freedom; $\mathrm{IPR}_{\mathrm{it}}$ - property rights index; $\mathrm{GDS}_{\mathrm{it}}$ - gross domestic product; $\mathrm{K}_{\mathrm{it}}$ - capital; $\mathrm{L}_{\mathrm{it}}-$ labor;

$\mathrm{IMP}_{\text {it }}$ - import of goods and services; $\mathrm{EXP}_{\mathrm{it}}$ - export of goods and services; $\mathrm{RD}_{\mathrm{it}}$ - expenses for research work;

$\mathrm{ROY}_{\mathrm{it}}$ - payments for the use of intellectual property rights, royalties; $\mathrm{FDI}_{\mathrm{it}}$ - foreign direct investment.

It is assumed that, compared to other usual key determinants of economic growth (Table 1) (capital, labor, foreign trade, foreign direct investment), the weight of industrial cooperation will be positive.

\section{Results}

The analysis of the obtained assessment data and the main tests of the model (Table 2) led to the conclusion that the level of state regulation in the field of protection of property rights has a positive impact on the cooperative activity of enterprises in European countries. This generally confirms our hypothesis about the presence of a causal effect if we consider the variable of cooperation in the meaning of the total number of co-operators. At the same time, the statistical significance in the specifications of model 1-3 is close to the minimum acceptable level of $10 \%$. In Specification 4, when using the (IPR $\mathrm{it}_{\mathrm{it}}$ ) with random effects, the coefficient of the property protection variable (at the level of 10\%) becomes statistically significant (at the level of 10\%) (0.537).

Table 2. The results of testing the FRAN_1 model - the method of least squares (OLS) with fixed and random effects

\begin{tabular}{|c|c|c|c|c|}
\hline \multirow{3}{*}{ Index } & 1st specification & 2nd specification & 3rd specification & 4th specification \\
\hline & \multicolumn{2}{|c|}{ fixed effects } & \multicolumn{2}{|c|}{ random effects } \\
\hline & FRAN_1 & $F R A N \_1$ & $F R A N \_1$ & FRAN_1 \\
\hline$I E F$ & $0.971(1.31)$ & & $0.844(1.30)$ & \\
\hline$I P R$ & & $0.568(1.64)$ & & $0.537 *(1.91)$ \\
\hline Constant & $1.929(0.62)$ & $3.618 * *(2.48)$ & $2.464(0.90)$ & $3.750 * * *(3.13)$ \\
\hline Number of observations & 100 & 100 & 100 & 100 \\
\hline Number of countries & 20 & 20 & 20 & 20 \\
\hline
\end{tabular}

Notes: the absolute value of t-statistics in brackets; * - significance at the level of $10 \% ; * *$ - significance at the level of $5 \%$; *** - significance at the level of $1 \%$. 
A weak statistical significance of the coefficients of the institutional variable, assessing its impact on the activities of industrial cooperation, can be explained, first, by imperfection of measuring the level of protection of property rights; secondly, the need to expand the number of observations by including more countries in the study and increasing the scope of the survey; thirdly, the effect of the influence of changes in state regulation on industrial cooperation in the same time period is ambiguous. The application of certain lagged values can help to understand the relationship between the protection of property rights and cooperative activities. These recommendations can serve as promising trends for further research about this problem.

Let us analyze the results of testing the influence of state regulation in the sphere of protection of property rights on the activities of industrial cooperation (Table 3) through the parameter of the number of enterprises in the cooperative sector.

Table 3. The results of testing the FRAN_2 model - the method of least squares (OLS) with fixed and random effects

\begin{tabular}{|c|c|c|c|c|}
\hline \multirow{3}{*}{ Index } & 1st specification & 2nd specification & 3rd specification & 4th specification \\
\hline & \multicolumn{2}{|c|}{ fixed effects } & \multicolumn{2}{|c|}{ random effects } \\
\hline & $F R A N \_2$ & $F R A N \_2$ & $F R A N \_2$ & $F R A N \_2$ \\
\hline$I E F$ & $-2.273(0.43)$ & & $0.606(0.48)$ & \\
\hline$I P R$ & & $-5.902 * *(2.47)$ & & $-0.029(0.06)$ \\
\hline Constant & $19.192(0.86)$ & $34.466 * * *(3.43)$ & $7.078(1.33)$ & $9.746 * * *(4.74)$ \\
\hline Number of observations & 82 & 82 & 82 & 82 \\
\hline Number of countries & 20 & 20 & 20 & 20 \\
\hline
\end{tabular}

Notes: the absolute value of t-statistics in brackets; * - significance at the level of $10 \%$; ** - significance at the level of $5 \%$; $* * *$ significance at the level of $1 \%$.

The test results indicate that the specification 2 of the model has a high statistical significance. This confirms our idea that the strengthening of state regulation in the field of protection of property rights (including intellectual property) can be inversely related to the growth in the number of companies that will be committed to cooperative activities. In other words, weak regulation in the field of protection of property rights can become a motivational incentive for cooperators to develop their activities, creating a greater number of cooperative enterprises.

A possible explanation for this result is that in a more liberal protection of property rights the risks of industrial cooperation (risks of liability for non-observance of rights) are generally reduced. A more severe responsibility, for example, for infringement of trademark rights may lead to more cautious behavior, and thus should restrain the development of enterprises in the field of industrial cooperation.

However, testing the specifications 1, 3 and 4 shows that the statistical significance of the model FRAN_2 is far from the minimum allowable value. The use of such an alternative measure of industrial cooperation as the number of enterprises participating in cooperative activities makes the coefficient of industrial cooperation statistically insignificant. This can be justified by imperfection of the measure of industrial cooperation in the number of enterprises participating in cooperative activities, or the problem in the data retrieval, which may serve as a subject for further research. 


\section{Discussion}

Let us analyze the influence of industrial cooperation on the economic growth of 20 European countries of our series. To test this hypothesis, we apply an econometric analysis of table data with fixed effects. It is important to include all the key factors in the specification of the model that have a systemic impact on economic growth and which are inherent in the economies of countries from our series. Economic theory and empirical studies show that open economies grow faster than closed one due to liberalized foreign trade, attracting foreign investment, sharing of technological achievements and knowledge (Organisation for Economic Co-operation and Development, 2010; Van den Berg, \& Lewer, 2015; Oosterbaan et al., 2000; Carlberg, 1997). In a number of studies, the important role of institutions in promoting economic growth has been proved (Corkhill, 2002; Dawson, 1998; Vijayaraghavan, \& Ward, 2001; Scully, 1988; Gwartney et al., 2005). At the same time, to study the influence of political and economic factors of international economic integration on economic growth, it is necessary to take into account capital and labor as the basic factors of production according to the production function of Cobb-Douglas. Let us note once again that our idea is to have a positive correlation between the usual key determinants of economic growth (capital, labor, foreign trade, and foreign direct investment) and industrial cooperation.

In order to overcome the problem of the completeness of the model specification in the evaluation equation, we take into account other possible determinants of economic growth, such as research activities (research and development costs, $\mathrm{RD}_{\mathrm{it}}$ in logarithms), payments for the use of intellectual property rights - royalties $\mathrm{ROY} \mathrm{Y}_{\mathrm{it}}$ ), and the Index of Economic Freedom ( $\left(\mathrm{IEF}_{\mathrm{it}}\right)$. The summary form of the equation of economic growth in this case is the following:

$$
G D P_{i t}=a_{1} K_{i t}+a_{2} L_{i t}+a_{3} E X P_{i t}+a_{4} I M P_{i t}+a_{5} F D I_{i t}+a_{6} F R A N_{i t}+a_{7} R D_{i t}+a_{8} R O Y_{i t}+a_{9} I N S T I T_{i t}+c_{i}+u_{i t}
$$

where $\mathrm{i}$ and $\mathrm{t}$ are countries and time periods, respectively; $\mathrm{c}_{\mathrm{i}}$ is indeterminate fixed effect (by countries), "shaded effect"; $u_{\text {it }}$ is a calculation error.

The results of testing the influence of industrial cooperation on economic growth for a sample of countries are shown in Table 4.

Table 4. Results of testing the model of industrial cooperation influence on economic growth the method of least squares (OLS) with fixed effects

\begin{tabular}{|c|c|c|c|c|c|c|}
\hline \multirow{2}{*}{ Index } & Test 1 & Test 2 & Test 3 & Test 4 & Test 5 & Test 6 \\
\hline & $G D P$ & $G D P$ & $G D P$ & $G D P$ & $G D P$ & GDP \\
\hline$K$ & $\begin{array}{l}0.122 * * * \\
(5.34)\end{array}$ & $\begin{array}{l}0.141 * * * \\
(6.19)\end{array}$ & $\begin{array}{l}0.119 * * * \\
(6.24)\end{array}$ & $\begin{array}{l}0.152 * * * \\
(5.67)\end{array}$ & $\begin{array}{l}0.147 * * * \\
(4.60)\end{array}$ & $\begin{array}{l}0.135 * * * \\
(4.12)\end{array}$ \\
\hline$L$ & $\begin{array}{l}0.487 \text { *** } \\
(3.42)\end{array}$ & $\begin{array}{l}0.376 * * * \\
(2.66)\end{array}$ & $\begin{array}{l}0.394 * * * \\
(3.50)\end{array}$ & $\begin{array}{l}0.430 * * \\
(2.58)\end{array}$ & $\begin{array}{l}0.453 \text { ** } \\
(2.28)\end{array}$ & $\begin{array}{l}0.541 * * \\
(2.61)\end{array}$ \\
\hline$E X P$ & $\begin{array}{l}0.101 * \\
(1.96)\end{array}$ & $\begin{array}{l}0.119 * * \\
(2.41)\end{array}$ & $\begin{array}{l}0.147 * * * \\
(3.62)\end{array}$ & $\begin{array}{l}0.105 * * \\
(2.07)\end{array}$ & $\begin{array}{l}0.106 \\
(1.66)\end{array}$ & $\begin{array}{l}0.077 \\
(1.16)\end{array}$ \\
\hline$I M P$ & $\begin{array}{l}0.092 \\
(1.50) \\
\end{array}$ & $\begin{array}{l}0.041 \\
(0.67) \\
\end{array}$ & $\begin{array}{l}0.042 \\
(0.88) \\
\end{array}$ & $\begin{array}{l}0.032 \\
(0.49) \\
\end{array}$ & $\begin{array}{l}0.037 \\
(0.43) \\
\end{array}$ & $\begin{array}{l}0.070 \\
(0.80) \\
\end{array}$ \\
\hline$F D I$ & $\begin{array}{l}0.001 \\
(0.28)\end{array}$ & $\begin{array}{l}0.002 \\
(0.64)\end{array}$ & $\begin{array}{l}0.001 \\
(0.52)\end{array}$ & $\begin{array}{l}0.003 \\
(0.95)\end{array}$ & $\begin{array}{l}0.003 \\
(0.91)\end{array}$ & $\begin{array}{l}0.004 \\
(1.30)\end{array}$ \\
\hline FRAN_l & & $\begin{array}{l}0.030 * * * \\
(2.80)\end{array}$ & & $\begin{array}{l}0.028 * * \\
(2.50)\end{array}$ & $\begin{array}{l}0.026 * * \\
(2.20)\end{array}$ & $\begin{array}{l}0.023 * \\
(1.95)\end{array}$ \\
\hline$F R A N \_2$ & & & $\begin{array}{l}-0.002 \\
(1.60) \\
\end{array}$ & & & \\
\hline$R D$ & & & & $\begin{array}{l}0.029 \\
(1.16)\end{array}$ & $\begin{array}{l}0.019 \\
(0.64)\end{array}$ & $\begin{array}{l}0.005 \\
(0.16)\end{array}$ \\
\hline
\end{tabular}


The International Journal

ENTREPRENEURSHIP AND SUSTAINABILITY ISSUES

ISSN 2345-0282 (online) http://jssidoi.org/jesi/

2018 Volume 5 Number 3 (March)

http://doi.org/10.9770/jesi.2018.5.3(4)

\begin{tabular}{|c|c|c|c|c|c|c|}
\hline \multirow{2}{*}{ Index } & Test 1 & Test 2 & Test 3 & Test 4 & Test 5 & Test 6 \\
\hline & $G D P$ & $G D P$ & $G D P$ & $G D P$ & $G D P$ & $G D P$ \\
\hline$R O Y$ & & & & & $\begin{array}{l}0.010 \\
(0.88)\end{array}$ & $\begin{array}{l}0.009 \\
(0.79)\end{array}$ \\
\hline INSTIT & & & & & & $\begin{array}{l}0.112 \\
(1.40)\end{array}$ \\
\hline Constant & $\begin{array}{l}11.008 * * * \\
(4.93)\end{array}$ & $\begin{array}{l}12.950 * * * \\
(5.79)\end{array}$ & $\begin{array}{l}12.627 * * * \\
(7.23)\end{array}$ & $\begin{array}{l}12.357 * * * \\
(4.61)\end{array}$ & $\begin{array}{l}11.720 * * * \\
(3.63)\end{array}$ & $\begin{array}{l}10.053 * * * \\
(2.94)\end{array}$ \\
\hline Observations & 92 & 92 & 75 & 88 & 76 & 76 \\
\hline $\begin{array}{l}\text { Number } \\
\text { countries }\end{array}$ & 20 & 20 & 20 & 20 & 17 & 17 \\
\hline$R^{2}$ & 0.84 & 0.86 & 0.90 & 0.87 & 0.86 & 0.87 \\
\hline
\end{tabular}

Notes: the absolute value of t-statistics in brackets; ${ }^{*}$ - significance at the level of $10 \%$; ** - significance at the level of 5\%;

*** - significance at the level of $1 \%$.

As you can see from the specifications $2,4,5,6$, the coefficient of variable cooperative activity, which is measured as the number of co-operators, is positive and statistically significant but its value is 10 times smaller than the labor force coefficient; 5 times less than the capital ratio; 4 times less than the export ratio. Based on this fact, we come to the conclusion that industrial cooperation has a direct and confident influence on economic growth. The conditional share of industrial cooperation allows providing additional economic growth at the level of $2.3-3.0 \%$ per year.

Although the economic importance of industrial cooperation for economic growth is not so significant in comparison with key determinants (as you can see from the value of the coefficient of industrial cooperation in regression), industrial co-operation enhances the factor impact of the labor force by $7-10 \%$; it enhances the factor impact of capital on economic growth by $18-20 \%$, increases the factor impact of exports on economic growth by 25-26\%. The obtained results correspond to the initial expectations and fully correlate with the concept of the study. The offered hypothesis has been confirmed; industrial cooperation is important for economic growth; its restriction can lead to a reduction in the gross domestic product to $2.3-3.0 \%$.

It becomes obvious that industrial cooperation plays a promoting role. From the point of view of economic theory, industrial cooperation as a form of management can significantly accelerate the pace of economic development. In addition, the promotion of industrial cooperation contributes to the increase in incomes of the population, as the number of consumers of products and services of cooperative companies' increases, as well as the number of those who can create their own business on the basis of industrial cooperation. The uniqueness of industrial cooperation lies in the fact that it reduces the risk of failure in business, creates additional jobs, gives a positive experience and knowledge, and, therefore, it is a factor in the development of entrepreneurship. All this can serve as a source of economic growth for the country (or group of countries) and the driving force for the global economy.

At the same time, the development of integration and cooperation in industry between independent enterprises is a factor of increasing risks and uncertainty (Kuzmin, 2012). In terms when the activity of the organization depends on the work of other counterparties, unconditionally, there is an increase in the uncertainty regarding the provision of contractual obligations in terms of volume, quality and timing. On the other hand, industrial cooperation can be viewed as a tool for diversification. Then the overall commercial risk and uncertainty will be diffused until the number of elements of diversification passes a crucial point (after that, an additional uncertainty is created that is connected with the management and coordination of processes). As a consequence, diversification has applicability limits as a risk management tool (Kuzmin, 2015). 
It is usual to single out the main risks from cooperation, for example, the risk of dependence on the partner for cooperation, the risk of secret information leak as a result of incorrect actions of the partner (partners) within the framework of industrial cooperation, the risk associated with the application of economic legislation of another country (for international industrial cooperation), the risk associated with the emergence of quasi-cooperation (Bulatov, 2010b).

\section{Conclusions}

In terms of the development of the innovative economy, the competition between enterprises is changed and transformed into the development of integration and cooperation. The industrial cooperation to a large extent is based on the comparative advantages of a particular territory (region, country) or industry. Competitive and imports pressure force companies to use interregional differences in wages and qualified personnel. This is due to the increased role of transnational corporations, the growing demand for high-tech goods and services, and limited resources.

Our study was designed to determine the degree of influence of industrial cooperation on economic growth. All this determines the specification of significant factors of influence that go beyond the traditional perception. The known determinants of economic growth, such as capital, labor, foreign trade and foreign direct investment, have been supplemented. The study also took into account research activities (concerning the indicator of expenditure on research and development), payments for the use of intellectual property rights and the subjective Index of Economic Freedom. Two main models were formed on the analysis as a variable of cooperation in the number of co-operators and in the number of enterprises in the cooperative sector. The test results showed that the model based on the number of enterprises in the cooperative sector is statistically insignificant. The remaining model allowed confirming and justifying the proposals made.

The main hypothesis of the study is that the institutional protection of property rights is a decisive factor in the development of cooperation. The test results indicate that the specification of such a model has a high statistical significance. This allows us to conclude that the strengthening of state regulation in the field of protection of property rights (including intellectual property) can be inversely related to the growth in the number of companies that are committed to cooperative activities. In other words, weak regulation in the field of protection of property rights can become a motivational incentive for cooperators to develop their activities, creating a greater number of cooperative enterprises.

The conducted evaluations also indicate that the conditional share of industrial cooperation allows providing additional economic growth at the level of 2.3-3.0\% per year for the period of forecast observation. Although the industrial cooperation for economic growth is not so significant in comparison with key traditional determinants, nevertheless cooperation strengthens the factor influence of the labor force on economic growth by 7-10\%; factor impact of capital - by $18-20 \%$; factor impact of exports - by $25-26 \%$. This allows concluding that cooperation becomes a reproductive base of socio-economic and scientific and technological progress. 
The International Journal

ENTREPRENEURSHIP AND SUSTAINABILITY ISSUES

ISSN 2345-0282 (online) http://jssidoi.org/jesi/

2018 Volume 5 Number 3 (March)

http://doi.org/10.9770/jesi.2018.5.3(4)

\section{References}

Adams, J.D., \& Marcu, M. (2004). R\&D Sourcing, Joint Ventures and Innovation: A Multiple Indicators Approach. Cambridge: National Bureau of Economic Research Inc.

Akhtaryev, R.R. (2010). Prospects for the Development of Economic Relations and Industrial Cooperation. Regional Economy: Theory and Practice, 47, 69-76.

Batkovskiy, A.M., Semenova, E.G., Trofimets, V.Ya., Trofimets, E.N., \& Fomina, A.V. (2017). Modified method for sensitivity analysis of investment projects efficiency criteria. Journal of Applied Economic Sciences, 4(50): 1116-1131.

Berg, D.B., Davletbaev, R.H., Nazarova, Y.Y., \& Zvereva, O.M. (2017). The Detailed Structure of Local Entrepreneurial Networks: Experimental Economic Study. Communications in Computer and Information Science, 661, 81-90. https://doi.org/10.1007/978-3-319$\underline{52920-2 \_8}$

Bilorus, O.G., \& Bilorus, O.H. (1990). Mechanism of National Economic Integration. Naukova Dumka.

Bonin, J., \& Putterman, L. (2013). Economics of Cooperation and the Labour-Managed Economy. London: Taylor \& Francis.

Bulatov, A.N. (2010a). Industrial Cooperation in the Context of Institutional and Neoinstitutional Theory. Economic Research, $2,6$.

Bulatov, A.N. (2010b). Negative Forms of Cooperation. Economic Studies, 2, 3.

Carlberg, M. (1997). International Economic Growth. Berlin: Springer Science \& Business Media. http://dx.doi.org/10.1007/978-3-642$\underline{59256-0}$

Corkhill, D. (2002). Development of the Portuguese Economy: A Case of Europeanization. New York: Routledge.

Dawson, J.D. (1998). Institutions, Investment, and Growth: New Cross-Country and Panel Data Evidence. Economic Inquiry, 36, 603-619. https://doi.org/10.1111/j.1465-7295.1998.tb01739.x

De Groot, J.P., \& Plantinga, J. (1992). The Future of Agrarian Reform in Nicaragua. In W. Pelupessy, \& J. Weeks (Eds.), Economic Maladjustment in Central America. Springer.

Glaister, K.W., \& Buckley, P.J. (1996). Strategic Motives for International Alliance Formation. Journal of Management Studies, 33(3), 301-332. https://doi.org/10.1111/j.1467-6486.1996.tb00804.x

Gomes-Casseres, B., Hagedoorn, J., \& Jaffe, A. (2006). Do Alliances Promote Knowledge Flows. Journal of Financial Economics, 80, 533. https://doi.org/10.1016/i.jfineco.2004.08.011

Gwartney, J., Stroup, R., Sobel, R., \& Macpherson, D. (2005). Economics: Private and Public Choice. Thomson South-Western.

Haller, M. (2008). European Integration as an Elite Process: The Failure of a Dream? Routledge.

Ignatavičius, R.; Tvaronavičienė, M.; Piccinetti, L. (2015). Sustainable development through technology transfer networks: case of Lithuania. Journal of Security and Sustainability Issues, 4(3), 261-267. DOI: http://dx.doi.org/10.9770/jssi.2015.4.3(6)

Kozma, F. (1982). Economic Integration and Economic Strategy. Springer Science \& Business Media. http://dx.doi.org/10.1007/978-94$\underline{017-1362-7}$

Kuroiwa, I. (2012). Economic Integration and the Location of Industries: The Case of Less Developed East Asian Countries. Palgrave Macmillan. https://doi.org/10.1057/9780230389427

Kuzmin, E.A. (2012). Assessment and Analysis of Riskiness of the Development of the Industrial Complex of the Region: Meso- and Micro- Levels (the Sverdlovsk Region, as an Example). Economics and Entrepreneurship, 6(29), 100-104.

Kuzmin, E.A. (2015). Fundamentals in Systematics of Uncertainty Management Theory. Mediterranean Journal of Social Sciences, 6( 5, S2), 380-389. https://doi.org/10.5901/mjss.2015.v6n5s2p380 
The International Journal

ENTREPRENEURSHIP AND SUSTAINABILITY ISSUES

ISSN 2345-0282 (online) http://jssidoi.org/jesi/

2018 Volume 5 Number 3 (March)

http://doi.org/10.9770/jesi.2018.5.3(4)

Nikulina, O.V., \& Kuznetsov, A.A. (2016). International Cooperation as a Mechanism for Interaction of Industrial Enterprises in the Field of Innovation. National Interests: Priorities and Security, 4(337), 88-102.

Obecny, K., \& Sanders, G. (2017). U.S.-Canadian Defense Industrial Cooperation. Rowman \& Littlefield.

Oosterbaan, M.S., de Ruyter van Steveninck, T., \& van der Windt, N. (Eds.). (2000). The Determinants of Economic Growth. New York: Springer Science \& Business Media. http://dx.doi.org/10.1007/978-1-4615-4483-8

Organisation for Economic Co-operation and Development. (2010). Trade and the Economic Recovery: Why Open Markets Matter. OECD. Retrieved February 12, 2018, from http://www.oecd.org/trade/45293795.pdf

Paprzycki, R. (2005). Interfirm Networks in the Japanese Electronics Industry. Routledge. http://dx.doi.org/10.4324/9780203422335

Petrishcheva, I.V. (2011). Industrial Cooperation in the Context of Interaction of Small and Large Enterprises: Essence and Forms. Almanac of Modern Science and Education, 1, 168-170.

Prause, G.; Atari, S. (2017). On sustainable production networks for Industry 4.0. Entrepreneurship and Sustainability Issues, 4(4), 421431. https://doi.org/10.9770/jesi.2017.4.4(2)

Restakis, J. (2010). Humanizing the Economy: Co-operatives in the Age of Capital. Gabriola Island, Canada: New Society Publishers.

Rodina, L.A. (1990). East-West Industrial Cooperation: Problems and Prospects. Moscow: Nauka.

Scully, G.W. (1988). The Institutional Framework and Economic Development. Journal of Political Economy, 96(3), 652-662. https://doi.org/10.1086/261555

Semenov, A.A. (2011). Management of Cooperation in Integrated Industrial Structures. Public Administration, $27,12$.

Shevchenko, B.I., \& Savinova, M.V. (2009). International Industrial Cooperation: Place and Role of Russia. Vestnik RSUH. Series: Political science. History. International relationships. Foreign Regional Studies. Oriental studies, 14, 170-190.

Soboleva, Yu.P. (2007). Management of Industrial Cooperation in Integrated Associations. Problems of the Modern Economy, 3, $153-158$.

Van den Berg, H., \& Lewer, J.J. (2015). International Trade and Economic Growth. New York, USA: Taylor \& Francis, Routledge.

Vijayaraghavan, M., \& Ward, W.A. (2001). Institutions and Economic Growth: Empirical Evidence from a Cross-National Analysis. Working Paper Number 001302. Clemson, S.C.: Center for International Trade, Clemson University.

Yin, R. (2016). Theory and Methods of Metallurgical Process Integration. Elsevier.

Zheng, L., \& Possel-Dölken, F. (2002). Strategic Production Networks. Berlin: Springer Science \& Business Media. http://dx.doi.org/10.1007/978-3-540-24812-5 
The International Journal

ENTREPRENEURSHIP AND SUSTAINABILITY ISSUES

ISSN 2345-0282 (online) http://jssidoi.org/jesi/

2018 Volume 5 Number 3 (March)

http://doi.org/10.9770/jesi.2018.5.3(4)

\section{Annex}

Table A. Table of data - the number of co-operators

\begin{tabular}{|c|c|c|c|c|c|}
\hline \multirow{2}{*}{ Country } & \multicolumn{5}{|c|}{ Number of cooperators } \\
\hline & 2017 & 2018 & 2019 & 2020 & 2021 \\
\hline Belgium & 100 & 200 & 320 & 360 & 350 \\
\hline Austria & 390 & 400 & 410 & 420 & 420 \\
\hline Croatia & 125 & 137 & 150 & 168 & 175 \\
\hline Czech Republic & 131 & 137 & 150 & 168 & 190 \\
\hline Denmark & 180 & 185 & 186 & 188 & 188 \\
\hline Finland & 220 & 255 & 265 & 270 & 270 \\
\hline France & 1,137 & 1,229 & 1,396 & 1,477 & 1,569 \\
\hline Germany & 910 & 950 & 980 & 980 & 990 \\
\hline Greece & 570 & 566 & 563 & 450 & 456 \\
\hline Hungary & 330 & 350 & 350 & 361 & 361 \\
\hline Italy & 817 & 852 & 869 & 883 & 885 \\
\hline Netherlands & 676 & 687 & 692 & 714 & 739 \\
\hline Poland & 387 & 491 & 584 & 697 & 746 \\
\hline Portugal & 501 & 521 & 524 & 570 & 578 \\
\hline Slovenia & 103 & 106 & 107 & 103 & 106 \\
\hline Spain & 850 & 875 & 919 & 934 & 947 \\
\hline Sweden & 350 & 400 & 550 & 640 & 700 \\
\hline Switzerland & 275 & 275 & 275 & 275 & 275 \\
\hline United Kingdom & 809 & 838 & 845 & 900 & 929 \\
\hline
\end{tabular}

Source: CECOP - CICOPA Europe is the European confederation of industrial and service cooperatives. Retrieved January 12, 2018, from http://www.cecop.coop/-Publications-

Table B. The number of cooperative enterprises

\begin{tabular}{|l|l|l|l|l|l|}
\hline \multirow{2}{*}{ Country } & \multicolumn{5}{c|}{ Number of cooperative enterprises } \\
\cline { 2 - 6 } & \multicolumn{1}{|c|}{$\mathbf{2 0 1 7}$} & $\mathbf{2 0 1 8}$ & $\mathbf{2 0 1 9}$ & $\mathbf{2 0 2 0}$ & \multicolumn{1}{c|}{$\mathbf{2 0 2 1}$} \\
\hline Belgium & 3,500 & - & - & - & 11,000 \\
\hline Austria & - & 7,200 & - & 8,000 & - \\
\hline Croatia & 900 & - & - & 900 & 1,000 \\
\hline Czech Republic & - & - & - & 3,476 & 4,366 \\
\hline Denmark & 7,200 & 7,307 & 7,520 & 7,500 & 7,500 \\
\hline Finland & 3,500 & 4,200 & 4,400 & 4,500 & 4,500 \\
\hline France & 47,291 & 50,127 & 53,101 & 58,351 & 62,041 \\
\hline Germany & 55,000 & 57,000 & 61,000 & 65,500 & 66,900 \\
\hline Greece & 11,650 & 12,796 & 12,048 & 12,084 & 11,113 \\
\hline Hungary & 17,000 & 18,000 & 19,000 & 20,000 & 20,000 \\
\hline Italy & 52,725 & 53,434 & 53,313 & 54,013 & 54,096 \\
\hline Netherlands & 28,219 & 28,466 & 29,021 & 29,509 & 29,781 \\
\hline Poland & 22,450 & 26,781 & 32,589 & 37,218 & 42,522 \\
\hline Portugal & 11,271 & 12,206 & 13,000 & 12,016 & 11,760 \\
\hline Slovenia & 1,213 & 1,525 & 1,527 & 1,532 & 1,540 \\
\hline Spain & 59,182 & 58,305 & 57,139 & 56,444 & 58,279 \\
\hline Sweden & 10,000 & 15,000 & 18,000 & 24,000 & 26,000 \\
\hline Switzerland & - & - & - & - & - \\
\hline United Kingdom & 36,200 & 36,600 & 36,500 & 38,600 & 40,100 \\
\hline Source: CECOP
\end{tabular}

Source: CECOP - CICOPA Europe is the European confederation of industrial and service cooperatives. Retrieved January 12, 2018, from http://www.cecop.coop/-Publications 
The International Journal

ENTREPRENEURSHIP AND SUSTAINABILITY ISSUES

ISSN 2345-0282 (online) http://jssidoi.org/jesi/

2018 Volume 5 Number 3 (March)

http://doi.org/10.9770/jesi.2018.5.3(4)

\begin{abstract}
Alena V. FOMINA, Doctor of Sc. (Economics), Professor, JSC "Central Research Institute of Economy Management and Information Systems "Electronics" (Moscow, Russian Federation). Research interests: regional economy, industrial economy, development strategies and restructuring, strategic planning, high-tech production structures, industry analysis, financial and economic planning, sustainable economic systems.
\end{abstract}

ORCID ID: orcid.org/0000-0002-5853-0309

Oksana N. BERDUYGINA, Cand. of Sc. (Pedagogic), Assistant professor, Department of Business Informatics and Mathematics, Tyumen Industrial University (Tyumen, Russian Federation). Research interests: mathematics, mathematical methods in economics, forecasting processes, statistical methods of information processing, institutional economy, risk and uncertainty, public-private partnership, sustainability.

ORCID ID: orcid.org/0000-0001-7038-3690

Alexander A. SHATSKY, applicant for candidate degree, Russian State Social University (Moscow, Russian Federation). Research interests: socio-economic development, multi-agent technologies, services, digital economy, management of economic systems, service management, regional complexes and clusters, sustainable economic systems.

ORCID ID: orcid.org/0000-0002-0402-9201

Register for an ORCID ID:

https://orcid.org/register

Copyright (C) 2018 by author(s) and VsI Entrepreneurship and Sustainability Center

This work is licensed under the Creative Commons Attribution International License (CC BY).

http://creativecommons.org/licenses/by/4.0/

C. (i) Open Access 